\title{
STORY MAPPING TECHNIQUE AND COMPREHENDING NARRATIVE TEXT
}

\author{
Dian Sartika Simanjuntak, Eka Sustri Harida, \& Zainuddin \\ IAIN Padangsidimpuan
}

email: diansartikasimanjuntak@gmail.com, haridaekasustri75@gmail.com, \& Zainuddin@gmail.com http://dx.doi.org/10.24952/tazkir.v5i2.2292

\begin{abstract}
Abstrak
Penelitian ini mendeskripsikan tentang pengaruh teknik Story Mapping untuk memahami teks naratif pada siswa kelas VIII SMP $\mathrm{N} 5$ Padangsidimpuan. Ada beberapa masalah dalam penelitian ini : 1). Siswa kesulitan dalam memahami teks, 2). Siswa tidak dapat menyatukan informasi yang telah dibaca dengan pengetahuan mereka sebelumnya, 3). Guru menggunakan teknik yang kurang tepat dalam mengajar pemahaman membaca. Jenis penelitian ini adalah penelitian eksperimen. Populasi dalam penelitian ini adalah seluruh siswa kelas VIII SMP N 5 Padangsidimpuan. Total populasi adalah 265 siswa. Lalu, sampel penelitian ini adalah dua kelas, VIII 5 sebagai kelas eksperimen yang terdiri dari 28 siswa dan VIII 6 sebagai kelas kontrol yang terdiri dari 28 siswa. Data dikumpulkan melalui pre-test dan post-test. Untuk menganalisa data, peneliti menggunakan rumus t-test. Berdasarkan perhitungan t-test, peneliti menemukan bahwa thitung $=8,03$ dan $t_{\text {table }}=1,67356$. Itu artinya thitung $>t_{\text {table }}(8,03>1,67356)$. Jadi, peneliti dapat menyimpulkan bahwa Ha diterima dan Ho ditolak. Ada pengaruh yang signifikan dari penggunaan teknik Story Mapping untuk memahami teks naratif pada siswa kelas VIII SMP N 5 Padangsidimpuan.
\end{abstract}

Kata Kunci: Reading Comprehension, Narrative Text, \& Story Mapping Technique.

\begin{abstract}
This research describes about the effect of Story Mapping Technique to comprehend narrative text at grade VIII students of SMP N 5 Padangsidimpuan. There were some problems in this research: 1) The students get difficulties in comprehending the text, 2) The students cannot combine the information that they have already read with their background knowledge, 3) The teacher uses inappropriate technique in teaching reading comprehension. The kind of this research was experimental research. The population of this research was all of the eight grade of SMP N 5 Padangsidimpuan. The total of population were 265 students. Then, the sample of the research was 2 classes, VIII 5 as experimental class that consist of 28 students and VIII 6 as control class that consist of 28 students. The data was derived from pre-test and post-test. To analyze the data, the researcher used t-test formula. Based on the calculation of t-test, the researcher found that $t_{\text {count }}=8.03$ and $t_{\text {table }}=1.67356$. It means $t_{\text {count }}>t_{\text {table }}(8.03>1.67356)$. So, the researcher could concludes that Ha was accepted and Ho was rejected. There was the significant effect of using Story Mapping Technique to comprehend narrative text at grade VIII students of SMP Negeri 5 Padangsidimpuan.
\end{abstract}

Keywords: Reading Comprehension, Narrative Text, E Story Mapping Technique. 
222 | TAZKIR: Jurnal Penelitian Ilmu-ilmu Sosial dan Keislaman

Vol. 05 No. 2 Desember 2019

\section{INTRODUCTION}

Reading is the fundamental of all aspects in learning. Reading is the process of interpreting the information from the text in order to construct the meaning. In this time, reading is not only from the printed text, but also from the internet. Comprehension is the main goal of reading process. In indonesian currriculum, reading comprehension has a position as one of the abilities for students to master English. In the current curriculum- 2013 curriculum (K13), there are some texts that must be learnt by junior high school students in Indonesia. Several examples of types of the text are narrative, procedure, descriptive, report, news items, exposition, spoof, explanation, and discussion. Among the texts which are mentioned above, the researcher choose narrative text because narrative text is considered as the most interesting text.

However, many students have difficulties in reading. ${ }^{1}$ There are many problems of the students when they learn English22, many students got difficulties in finding main ideas and information from the texts. The main problem of reading is the students get difficulties in comprehending the text. They get difficulties in understanding information from the text and finding the details, recognizing the specific information of the text, deciding word reference, getting the purpose of the reading, knowing the tense mostly used and also generic structure of reading text.

They cannot combine the information that they have already read with their background knowledge. They read the text slowly and open their dictionary to get the meaning of difficult words. It will disturb the process of comprehending the text. They tell that learning reading is boring because they read a text on an unfamiliar topic.

The teacher cannot make an interesting learning process in the classroom. The teacher asks the students to read the text. Then the students translate the text and every word which is inappropriate technique to make them understand the text. After translating the text, they answer the questions. As a result the students become bored and cannot enjoy the learning process in the classroom.

Dealing with the students' comprehension difficulties, teacher should take appropriate technique to help the students solve their difficulties in

${ }^{1}$ Hapsyah Sri Mei, Private Interview on March $18^{\text {th }}, 2019$ in SMP Negeri 5 Padangsidimpuan.

${ }^{2}$ Eka Sustri Harida, "Students' Ability and Difficulties in Understanding English Text (A Study at English Program IAIN Padangsidimpuan)," Journal.Tarbiyahiainib.Ac.Id 21, no. 3 (2014): 183-88, http://journal.tarbiyahiainib.ac.id/index.php/attalim/article/view/102. 
comprehending the text. Some of the popular techniques in teaching reading comprehension are Silent Reading, Semantic Mapping, Jigsaw, Skimming, Scanning, Story Mapping and another.

This research used story mapping as a technique to help the students to comprehend the text easier. Story maps outline the structure of a story with specific headings (such as setting, main character, events). Students filled the story mapping with single word or phrase each heading. Story maps are particularly appropriate for students, who may not be familiar with the discourse structure of a text. ${ }^{3}$ This is a technique to generate, visual and organize ideas into map based on the word, phrase, and sentences by using a diagram or a chart that usually shows key components of a story, for example, characters, setting, problem, action, and ending or resolution. For this reason, the researcher has interested to apply Story Mapping Technique to students' reading comprehension.

\section{THEORITICAL DESCRIPTION}

\section{Reading Comprehension}

Reading is one of the important skills needed by the students to get the information from written text. Marianne Celle-Murcia states reading as an interactive and socio cognitive process, involving a text, a reader, and social context in which the activity of reading takes place. ${ }^{4}$ Gillet and Temple in I Putu Sukmaantara et al. say that reading is a way of life, a lifetime habit, a passion avocation ${ }^{5}$. In other words, it is a useful activity that may change the mind of the readers and modify their behavior of life.

The other definition of reading comes from some experts, Linse states that reading is a set of skills that involves making sense and deriving meaning from

3J. Michael O' Malley and Lorraine Valdez Pierce, Authentic Assesment for English Language Learners Practical Approaches for Teachers (U.S.A: Addition Wesley Publishing Company, 1996), p.102-106.

${ }^{4}$ Marianne Celce- and Murcia, Teaching English as a Second or Foreign Language, Third Edit (New York: Heinle \& Heinle, 2001), p.154, https://doi.org/10.1103/PhysRevE.56.5524.

${ }^{5}$ I Putu Sukmaantara, Riza Kisfinata, Musli Ariani, “The Effect of Using Story Mapping Technique on Reading Comprehension Achievement of The Eight Year Students at MTs. Negeri

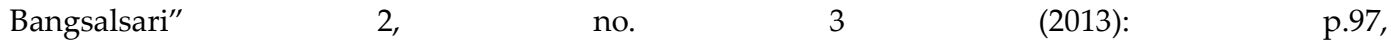
http://download.portalgaruda.org/article.php?article=175242\&val=5047\&title=The Effect of Using Story Mapping Technique on Reading Comprehension Achievement of The Eighth Year Students at Mts. Negeri Bangsalsari. 
224 | TAZKIR: Jurnal Penelitian Ilmu-ilmu Sosial dan Keislaman

Vol. 05 No. 2 Desember 2019

the printed words. ${ }^{6}$ In order to read, the students must able to decode (sound out) the printed words and also comprehend what they read. Akhondi, Malayeri, and Samad in Jaime N. Chavez et al. argue that students begin learning about reading through narrative story structures. ${ }^{7}$ Understanding the meaning of a text, or reading comprehension, is necessary to a student's ability to keep successful in school.

Reading comprehension as the process of simultaneously extracting and constructing meaning through interaction and involvement with written language. Comprehension entails three elements:

1) The reader who is doing the comprehending.

2) The text that is to be comprehended.

3) The activity in which comprehension is a part. ${ }^{8}$

Reading comprehension refers to reading for meaning, understanding, and entertainment. ${ }^{9}$ It involves higher-order thinking skills and is much more complex than merely decoding particular words.

From the definitions, it can be concluded that reading comprehension is mental process in which the readers try to connect what they read to their background knowledge in order to understand or comprehend the text.

\section{Story Mapping Technique}

One type of graphic organizer that can be helpful to students in organizing information is a story map. Sorrel in Necla and Kargin said that story map is a schema construction technique that involves teaching the relationships of parts of a story with each other to the reader and giving basic elements of the story in a schema in order to draw the attention of the reader. ${ }^{10}$ It is also stated by Reutzel in Richard T. Boon, a story map is a visual framework, typically presented in the

${ }^{6}$ Caroline T. Linse, Practical English Language Teaching: Young Learners, ed. David Nunan (New York: McGraw-Hill, 2005), p.69.

${ }^{7}$ Jaime N. Chavez, James Martinez, and Rachel S. Pienta, "Effects of Story Mapping on Third-Grade Students with Attention Deficit Hyperactivity Disorder," Journal of Pedagogy 6, no. 1 (2015): p.98, https://eric.ed.gov/?id=EJ1069783.

${ }^{8}$ RAND Reading Study Group and Catherine Snow, "Toward an R\&D Program in Reading Comprehension," in Reading for Understanding (RAND Corporation, 2002), p.11, https://www.jstor.org/stable/pdf/10.7249/mr1465oeri.10.pdf?refreqid=search\%3A8b0c394a35ebf0e47 7f4144795d5fa90.

${ }^{9}$ Linse, Practical English Language Teaching: Young Learners.

${ }^{10} \mathrm{Necla}$ Isikdogan and Tevhide Kargin, "Investigation of the Effectiveness of the Story-Map Method on Reading Comprehension Skills among Students with Mental Retardation," Educational Sciences: Theory \& Practice 10, no. 3 (2010): p.1512. 
form of a graphic organizer, to facilitate the acquisition of story structure and story elements. ${ }^{11}$ Story mapping is one instructional technique that can improve students reading comprehension skills of narrative text.

Actually this technique not only can be used for helping students' reading comprehension, but also for another skill and ability, such as grammar, vocabulary, or even speaking or writing. As stated by Harida ${ }^{12}$ that it can be also used for the students to improve vocabulary. Vocabulary teaching can be easily taught by using this technique. The students will be easier to understand and develop their vocabularies if the teachers of the students themselves use it as a way or process of vocabulary learning. So, it is stated that mind mapping or story mapping is good using for teaching or learning English in every kinds of level or skills.

\section{Narrative Text}

A narrative is simply a story that illustrates a point. That point is often about an emotion. ${ }^{13}$ Narrative is any written English text in which the writer wants to amuse, entertain people, and to deal with actual or vicarious experience in different ways. ${ }^{14}$ Abbott says that narrative is the principal way in which our species organizes its understanding of time and that the ability to manage time fluidly within a narrative allows events themselves to create order of time. ${ }^{15}$ Narrative is a basic and constant form of human expression regardless of ethnic origin, primary language, and enculturation.

\section{RESEARCH METHODS}

The kind of this research is quantitative research with experimental method. The researcher divides this research into two variables, those are independent

${ }^{11}$ Richard T. Boon et al., "A Review of Story Mapping Instruction for Secondary Students with LD," Learning Disabilities: A Contemporary Journal 13, no. 2 (2015): p.118, http://www.ldwldcj.org/images/open_access_articles/A-Review-of-Story-Mapping-Instruction.pdf.

12 Eka Sustri Harida, “Using Mind Mapping to Teach Vocabulary," English Education: English Journal for Teaching and Learning 3, no. 1 (2015): 1-14, http://repo.iainpadangsidimpuan.ac.id/176/1/1. Eka -min.pdf.

${ }^{13}$ John Langan, English Skills with Readings, Sevent Edition (McGraw-Hill, 2006), p.288, https://blaw05.files.wordpress.com/2015/10/english-skills-with-readings-7th-edition.pdf.

${ }^{14}$ Sanggam Siahaan and Kisno Shinoda, Generic Text Structure, First Edition (Yogyakarta: Graha Ilmu, 2008), p.73.

${ }^{15} \mathrm{H}$ Porter Abbott, The Cambridge Introduction to Narrative, First Edit (Cambridge: Cambridge University Press, 2002), p.3. 
226 | TAZKIR: Jurnal Penelitian Ilmu-ilmu Sosial dan Keislaman

Vol. 05 No. 2 Desember 2019

(Story Mapping Technique) and dependent (students' reading narrative text). The researchers use two classes in this research. One of the classes is taught with Story Mapping Technique and it called as experimental class or as a treatment. Meanwhile the other class is taught with Conventional Technique and called as control class. The population of this research are all of the second grade students of SMP Negeri 5 Padangsidimpuan that consist of 9 classes. The researchers choose VIII-5 as a experimental class (consist of 28 students) and VIII-6 as a control class (consist of 28 students). So, total of samples are 56 students. In collecting data the researcher used test for students. The kind of the test is multiple choice test. In giving the test, it is divided into two kinds; pre-test and post-test. The procedures are doing pre-test, treatment, and post-test. The data analyzed by using requirement test and hypothesis test. Requirement test have measured normality and homogenity of data. The researcher has used ChiQuadrate to calculate normality of the test. Homogeneity test was used to find out the variancess. The data were calculated by using Harley test. The hypothesis in this research used T-test to prove the hypothesis was accepted or was rejected. The hypothesis test was taken from pre-test and post-test data result. The T-tes result was calculated with basic assumption, if $t_{\text {count }}>t_{\text {table, }}$ it meant that hypothesis was accepted.

\section{RESEARCH FINDINGS}

\section{Data Description}

In this chapter researcher collected the data and gave the test about reading narrative text. The first, researcher gave a test to the students. The second, researcher collected the students' answer sheet and the last researcher checked the students' answer sheet and gave the score. The sample of this research was VIII 5 for experimental class and VIII 6 for control class. The test was divided into two aspect, they are pre-test and post-test. Pre-test was done before conducted the treatment, and post-test was done after conducted the treatment. The researcher used the formulation of T-test to test the hypothesis. Next, the researcher described the data as follow: 


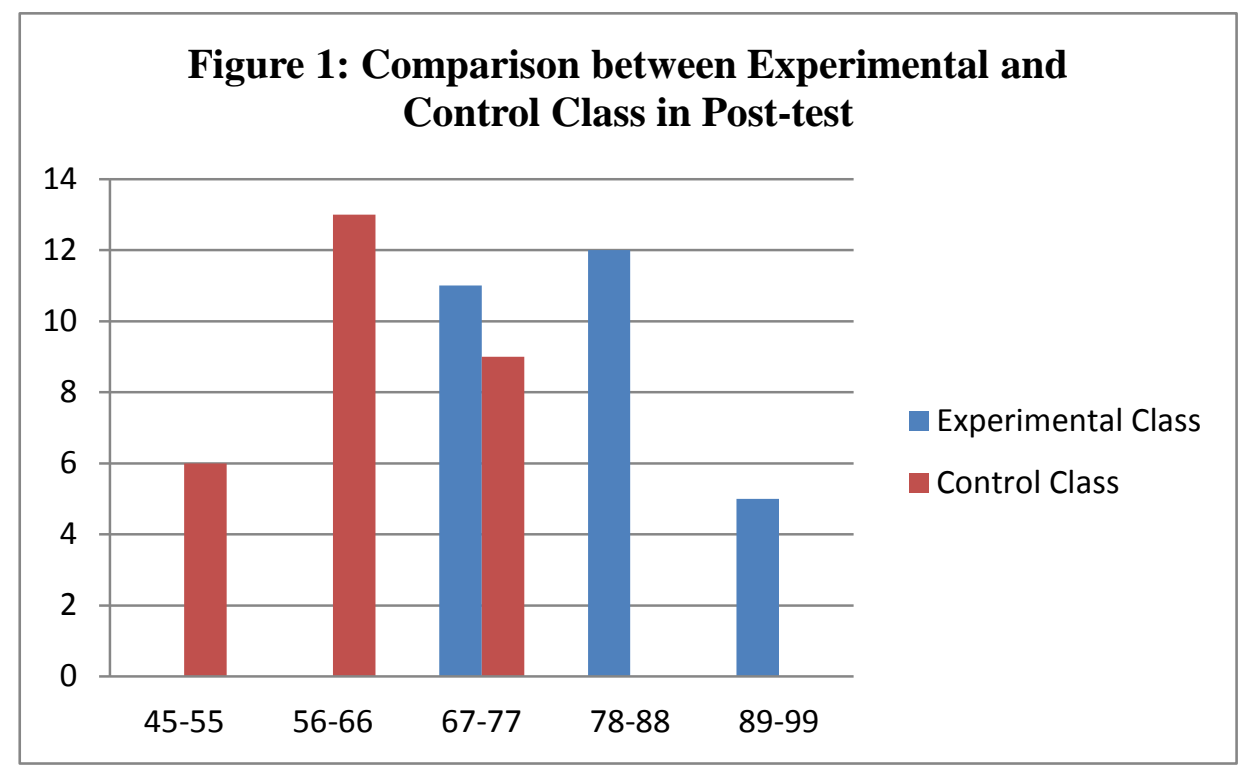

From histogram above, in experimental class, the frequency of students' score from 67 up to 77 was 11; 78 up to 88 was 12; 89 up to 99 was 5 students. In control class, the frequency of students' score from 45 up to 55 was 6; 56 up to 66 was 13 and 67 up to 77 was 9 students.

\section{Data Analysis}

\section{a. Requirement Test}

The result of the requirement test is the data were distributed normal and homogeneous. The calculated can be seen in the next table.

\section{Table 1}

Normality Test Experimental and Control Class

\begin{tabular}{|l|l|l|}
\multicolumn{2}{c}{ Pre-Test and Post- Test } \\
\hline \multirow{3}{*}{ Class } & \multicolumn{2}{|l|}{ Normality Test in Pre- Test } \\
\cline { 2 - 3 } & Xcount & Xtable \\
\hline Experimental Class & -1.81 & 11.070 \\
\hline Control Class & -10.65 & 11.070 \\
\hline \multirow{2}{*}{ Class } & Normality Test in Post test \\
\cline { 2 - 3 } & Xcount & Xtable \\
\hline Experimental Class & -6.12 & 11.070 \\
\hline Control Class & -13.83 & 11.070 \\
\hline
\end{tabular}


228 | TAZKIR: Jurnal Penelitian Ilmu-ilmu Sosial dan Keislaman

Vol. 05 No. 2 Desember 2019

Based on the above table researcher calculation, the score of experimental class in pre test $\mathrm{Lo}=-1.81<\mathrm{Lt}=11.070$ with $\mathrm{n}=28$ and control class $\mathrm{Lo}=-10.65<\mathrm{Lt}=11.070$ with $\mathrm{n}=28$, and real level $\alpha 0.05$. Cause $\mathrm{Lo}<\mathrm{Lt}$ in the both class. Meanwhile, the score of experimental in post- test class Lo = $-6.12<\mathrm{Lt}=11.070$ with $\mathrm{n}=28$ and control class $\mathrm{Lo}=-13.83<\mathrm{Lt}=11.070$ with $\mathrm{n}=28$, and real level $\alpha 0.05$. Cause Lo $<$ Lt in the both class. So, $\mathrm{H}_{a}$ was accepted. It means that experimental and control class were distributed normal.

Table 2

Homogeneity Test Experimental and Control Class Pre-Test and Post- Test

\begin{tabular}{|c|c|c|}
\hline \multirow{2}{*}{ Class } & \multicolumn{2}{|c|}{ Normality Test in Pre- Test } \\
\hline & $f_{\text {count }}$ & $\mathrm{f}_{\text {table }}$ \\
\hline Experimental Class & \multirow{2}{*}{\multicolumn{2}{|c|}{$1.41<2.66$}} \\
\hline Control Class & & \\
\hline \multirow{2}{*}{ Flass } & \multicolumn{2}{|c|}{ Normality Test in Post- Test } \\
\hline & $f_{\text {count }}$ & $\mathrm{f}_{\text {table }}$ \\
\hline Experimental Class & \multirow{2}{*}{\multicolumn{2}{|c|}{$1.15<2.66$}} \\
\hline Control Class & & \\
\hline
\end{tabular}

Table shows in pre- test the coefficient of $F_{\text {count }}=1.41$ was compared with $\mathrm{F}_{\text {table. }}$ Where $\mathrm{F}_{\text {table }}$ was determined at real $\alpha 0.05$, and the different numerator $\mathrm{dk}=\mathrm{N}-1=28-1=27$ and denominator $\mathrm{dk} \mathrm{N}-1=28-1=27$. So, by using the list of critical value at $\mathrm{F}$ distribution is got $\mathrm{F}_{\text {table }}=2.66$. It showed that $\mathrm{F}_{\text {count }} 1.41<$ Ftable 2.66. So, the researcher concluded that the variant from the data of the Students' Narrative Text Comprehension at Grade VIII SMP Negeri 5 Padangsidimpuan by experimental and control class was homogenous. Then in post- test The coefficient of $\mathrm{F}_{\text {count }}=1.15$ was compared with $\mathrm{F}_{\text {table. }}$ Where $\mathrm{F}_{\text {table }}$ was determined at real $\alpha 0.05$, and the different numerator $\mathrm{dk}=\mathrm{N}-1=28-1=27$ and denominator $\mathrm{dk} \mathrm{N}-1=28-1=27$. So, by using the list of critical value at $\mathrm{F}$ distribution is got $\mathrm{F}_{\text {table }}=2.66$. It showed that $\mathrm{F}_{\text {count }} 1.15<\mathrm{F}_{\text {table }} 2.66$. So, the researcher concluded that the variant from the data of the Students' Narrative Text Comprehension at Grade VIII SMP Negeri 5 Padangsidimpuan by experimental and control class was homogenous. 


\section{b. Hypothesis Test}

Hypothesis was gotten after requirement test of the data were done. The researcher had found that the data of students' narrative text comprehension in pre- test and post-test were distributed normal and data variances were homogeneous. The data would be analyzed to prove the hypothesis. The result of $\mathrm{t}$ - test displayed as follow:

Table 3

The Result of T-test

\begin{tabular}{|l|l|l|l|}
\hline \multicolumn{2}{|l|}{ Pre-Test } & Post-Test \\
\hline$t_{\text {count }}$ & $t_{\text {table }}$ & $t_{\text {count }}$ & $t_{\text {table }}$ \\
\hline-2.92 & 1.67356 & 8.03 & 1.67356 \\
\hline
\end{tabular}

Based on researcher calculation, researcher found that tcount 8.03 while table 1.67356 with opportunity $(1-\alpha)=1-5 \%=95 \%$ and $d k=n_{1}+n_{2}-2=28+$ $28-2=54$. Cause $t_{\text {count }}>t_{\text {table }}(8.03>1.67356)$, it means that hypothesis $\mathrm{H}_{\mathrm{a}}$ was accepted and $\mathrm{H}_{0}$ was rejected. So, there was the significant effect of using Story Mapping Technique to comprehend narrative text at grade VIII students SMP Negeri 5 Padangsidimpuan. In this case, the mean score of experimental class by using Story Mapping Technique was 81.1 and mean score of control class was 62.85 by using conventional technique.

\section{DISCUSSION}

Based on the result of this research, the researcher has proved what had been stated by Malley and Pierce ${ }^{16}$ that story maps outline the structure of a story with specific headings (such as setting, main character, events). Students filled the story mapping with single word or phrase each heading. Moreover, story maps are particularly appropriate for students, who may not be familiar with the discourse structure of a text. ${ }^{17}$ The theory stated that Story Mapping is an appropriate technique for reading comprehension, and in this research, the researcher found that the mean score of students' reading comprehension before using Story Mapping was 40.75 and after using Story Mapping was 81.1. It meant there was the effect of using Story Mapping on reading comprehension.

${ }^{16}$ Malley and Pierce, Authentic Assesment for English Language Learners Practical Approaches for Teachers.

${ }^{17}$ Malley and Pierce, Authentic Assesment for English Language Learners Practical Approaches for Teachers. 
The result above supported the previous research by some researchers. First, Novia Uswatun Hasanah on her thesis got the mean score in first cycle was 67 and second cycle was 89. ${ }^{18}$ Next, Norma Ita Scholichah on her thesis she got mean score of pre-test was 53.57 after applying Story Mapping Technique the mean score of post-test was $65.60 .{ }^{19}$ Then, Eka Sustri Harida on her research got the mean score in first cycle was 70.33 and the second cycle was $80.83 .{ }^{20}$ It shows the Story Mapping can improve students' reading comprehension.

From the above explanation, there was the increasing from the pre-test score to post-test score after using the technique among the related findings. Novia Uswatun Hasanah got the increasing 22, Norma Ita Sholichah got the increasing 12.03, and Eka Sustri Harida got the increasing 10.5. Meanwhile the researcher got the increasing was 40.35 .

Based on the result, the researcher has got the effect of Story Mapping Technique on students' reading comprehension. As known that mapping technique is not only good for teaching vocabulary ${ }^{21}$, but is also useful for teaching another skill, as reading. It is proved by Eka Sustri Harida, who found that $t_{\text {count }}=5.58>t_{\text {table }}=2.045$. The researcher also found that $t_{\text {count }}$ is higher than $t_{\text {table }}$ where $t_{\text {count }}$ was 8.03 and table was 1.67356 (8.03 >1.67356). It can be seen among the researches that the using of Story Mapping Technique gave the effect to students' reading comprehension especially at grade VIII Students of SMP Negeri 5 Padangsidimpuan. It means the theory has been proved where the students able to comprehend the reading material. Therefore, Story Mapping Technique has given the significant effect to the research that has been done by the researcher or the other researcher who mentioned in related finding and Story Mapping Technique is highly effective to help the English teacher in teaching learning process especially in reading comprehension.

\footnotetext{
${ }^{18}$ Novia Uswatun Hasanah, Improving Students ' Reading Comprehension in Narrative Texts With the Medium of Story Map (Semarang, 2016).

${ }^{19}$ Norma Ita Sholichah, "The Effect of Story Mapping on Reading Comprehension," Penelitian Ilmiah Intaj 1, no. 1 (2017): 29-48.

${ }^{20}$ Eka Sustri Harida, “Improving Students' Reading Narrative Text Comprehension Through Story Mapping Technique at Grade VIII MTSN 2 Padangsidimpuan" 05, no. 2 (2017): 103-17.

${ }^{21}$ Eka Sustri Harida, “Using Mind Mapping Technique to Teach Vocabulary," English Education Journal 3, no. 1 (2015): 1-12.
} 


\section{CONCLUSION}

From the result, the researcher concluded that Story Mapping Technique explored students' narrative text comprehension. it can be proved from the result of hypothesis test. The result of $\mathrm{t}$ - test for students' narrative text comprehension showed good score after given treatment it can be seen from the calculations of $t_{\text {count }}$ was 8.03 and table was 1.67356. The researcher concluded that there was the significant effect of using Story Mapping Technique to comprehend narrative text at grade VIII students SMP Negeri 5 Padangsidimpuan. So, it is suggested to the teachers to use this technique as their supporting teaching methods in order to help their students to get the best result in learning process. 
232 | TAZKIR: Jurnal Penelitian Ilmu-ilmu Sosial dan Keislaman

Vol. 05 No. 2 Desember 2019

\section{REFERENCES}

Abbott, H Porter. The Cambridge Introduction to Narrative. First Edit. Cambridge: Cambridge University Press, 2002.

Boon, Richard T, Michael Paal, Anna-Maria Hintz, and Melissa Cornelius-Freyre. "A Review of Story Mapping Instruction for Secondary Students with LD." Learning Disabilities: A Contemporary Journal 13, no. 2 (2015): 117-40.

Celce-, Marianne, and Murcia. Teaching English as a Second or Foreign Language. Third Edit. New York: Heinle \& Heinle, 2001. https://doi.org/10.1103/PhysRevE.56.5524.

Chavez, Jaime N., James Martinez, and Rachel S. Pienta. "Effects of Story Mapping on Third-Grade Students with Attention Deficit Hyperactivity Disorder." Journal of Pedagogy 6, no. 1 (2015): 95-121. https://doi.org/10.1515/jped-2015-0006.

Harida, Eka Sustri. “Improving Students' Reading Narrative Text Comprehension Through Story Mapping Technique at Grade VIII MTSN 2 Padangsidimpuan" 05, no. 2 (2017): 103-17.

- - . "Students' Ability and Difficulties in Understanding English Text (A Study at English Program IAIN Padangsidimpuan)." Journal.Tarbiyahiainib.Ac.Id $\quad 21$, no. $3 \quad$ (2014): 183-88. http://journal.tarbiyahiainib.ac.id/index.php/attalim/article/view/102.

- - . "Using Mind Mapping Technique to Teach Vocabulary." English Education Journal 3, no. 1 (2015): 1-12.

- - . "Using Mind Mapping to Teach Vocabulary." English Education: English Journal for Teaching and Learning 3, no. 1 (2015): 1-14. http://repo.iainpadangsidimpuan.ac.id/176/1/1. Eka -min.pdf.

Hasanah, Novia Uswatun. Improving Students ' Reading Comprehension in Narrative Texts With the Medium of Story Map. Semarang, 2016.

Isikdogan, Necla, and Tevhide Kargin. "Investigation of the Effectiveness of the Story-Map Method on Reading Comprehension Skills among Students with Mental Retardation." Educational Sciences: Theory E Practice 10, no. 3 (2010): 1509-27.

Langan, John. English Skills with Readings. Sevent Edi. McGraw-Hill, 2006.

Linse, Caroline T. Practical English Language Teaching: Young Learners. Edited by 
David Nunan. New York: McGraw-Hill, 2005.

Malley, J. Michael O', and Lorraine Valdez Pierce. Authentic Assesment for English Language Learners Practical Approaches for Teachers. U.S.A: Addition Wesley Publishing Company, 1996.

Riza Kisfinata, Musli Ariani, I Putu Sukmaantara. “The Effect of Using Story Mapping Technique on Reading Comprehension Achievement of The Eight Year Students at MTs. Negeri Bangsalsari” 2, no. 3 (2013): 97-104.

Sholichah, Norma Ita. "The Effect of Story Mapping on Reading Comprehension." Penelitian Ilmiah Intaj 1, no. 1 (2017): 29-48.

Siahaan, Sanggam, and Kisno Shinoda. Generic Text Structure. First Edit. Yogyakarta: Graha Ilmu, 2008.

Snow, RAND Reading Study Group and Catherine. "Toward an R\&D Program in Reading Comprehension." In Reading for Understanding, 11-17. RAND Corporation, 2002. 
234 | TAZKIR: Jurnal Penelitian Ilmu-ilmu Sosial dan Keislaman

Vol. 05 No. 2 Desember 2019

\title{
THE PERFORMANCE OF MANGUPA TRADITION IN ANGKOLA CUSTOM, MEDAN, INDONESIA
}

\author{
AKHIRIL PANE ${ }^{22}$, ROBERT SIBARANI ${ }^{23}$, IKHWANUDDIN \\ NASUTION $^{2}$, MUHAMMAD TAKARI ${ }^{2}$ \\ ${ }^{1}$ IAIN Padangsidimpuan, ${ }^{2}$ Universitas Sumatera Utara(USU), Medan
}

\footnotetext{
${ }^{22}$ Dosen IAIN Padangsidimpuan, Sumatera Utara. Indonesia

${ }^{23}$ Prof. Dr. Robert Sibarani, M.S, Dosen Program Doktor Linguistik, FIB Universitas Sumatera Utara Medan. Indonesia.
} 